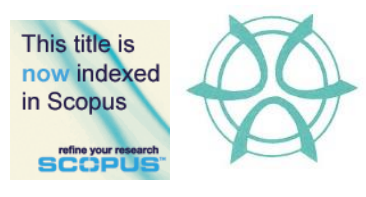

PLANNING MALAYSIA:

Journal of the Malaysian Institute of Planners

VOLUME 16 ISSUE 4 (2018), Page 130 - 142

\title{
FIGURE-GROUND MAPPING TO IDENTIFY URBAN FABRIC CHARACTERISTICS OF GEORGE TOWN HERITAGE ZONE
}

\author{
Tan Bee Eu${ }^{1} \&$ Teh Weng Jen ${ }^{2}$ \\ ${ }^{1 \& 2}$ School of Housing, Building and Planning \\ UNIVERSITI SAINS MALAYSIA
}

\begin{abstract}
The traditional Penang shophouses with its unique architecture elements constitutes the largest portion of the heritage zone which form a massive and coherently unique urban fabric. Conservation guidelines have been enforced to preserve the pre-war shophouses, by implementing classification of heritage buildings, façade/structural restoration, height control and so on. Are these measures truly effective to ensure meaningful intervention within the existing urban fabric? Preservation and conservation of the physical elements of existing shophouse will remain a superficial effort if no attempt is made to understand first the urban sense of place, the town planning language, the very fabric that weaves the solid formed by buildings with the void spaces of roads, parks, courtyards, foot paths and back lanes. Hebbert (2016) reckons figure-ground plans as the commonest type of image used in town planning, so common that it is easy to overlook their peculiar characteristics. This paper aims to revisit the power of figure-ground mapping and illustrates how its imaging will lead to deciphering the unique fabric of George Town. The author also employs an "Integrated Approach" (Trancik, 1986) by layering the two-dimensional solidvoid mappings with linkage study and sense of place to analyse unique patterns of two case study archetypes that reveal exceptional urban spatial characteristics of George Town that few have come to appreciate.
\end{abstract}

Keywords: figure ground mapping, planning mapping techniques, urban fabric, George Town 
PLANNING MALAYSIA

Journal of the Malaysia Institute of Planners (2018)

\section{INTRODUCTION}

Figure-ground perception as traced by Wagemans et al. (2012), germinated in the field of Gestalt psychology, developed by German psychologists Max Wertheimer and Wolfgang Kohler whom studied how people perceive forms in some sense of order in the disorderly world. Gestalt in German means "form" or "shape".

In architecture and urban space, Arnheim (1974) describes 'the enclosed surface tends to be figure, whereas the enclosing one will be ground'. The earliest influence of figure-ground in perceiving urban space can be seen from the Nolli Map of Rome, completed by Giambattista Nolli in 1748. Nolli represented built spaces with blocks and building shaded in dark shade, while enclosed public spaces as open civic spaces. This transits into black-white or as Solomon (2003) calls it as 'black plans', which was widely emulated in the nineteenth-century depictions of urban city maps. The figure-ground technique saw revival of interests by Colin Rowe (1920-99) where he rejected Modernism idea of a freestanding Architecture and advocated awareness of urban space characteristics defined by existing older buildings which emerged over the years.

Figure ground mapping, briefly defined as elements of solids or pochés that defines the edges of built forms and voids left by urban open space. Trancik (1986) described the three principal types of urban solids that has evolved in the traditional city; namely (A) public monument and institutions; (B) predominant field of urban blocks; (C) edge defining buildings (Figure 1). He also identified 5 type of urban voids that achieve varies functions in the city; such as (D) entry foyers which act as passageway between private and public space; (E) inner block voids as semiprivate transition zones; (F) network of streets and squares; $(\mathrm{G})$ parks and gardens as nodes that contrasts with urban solids forms; $(\mathrm{H})$ linear open space systems, such as riverways, wetlands which cut through urban solids establishing edges and create connections in larger scale (Figure 1).
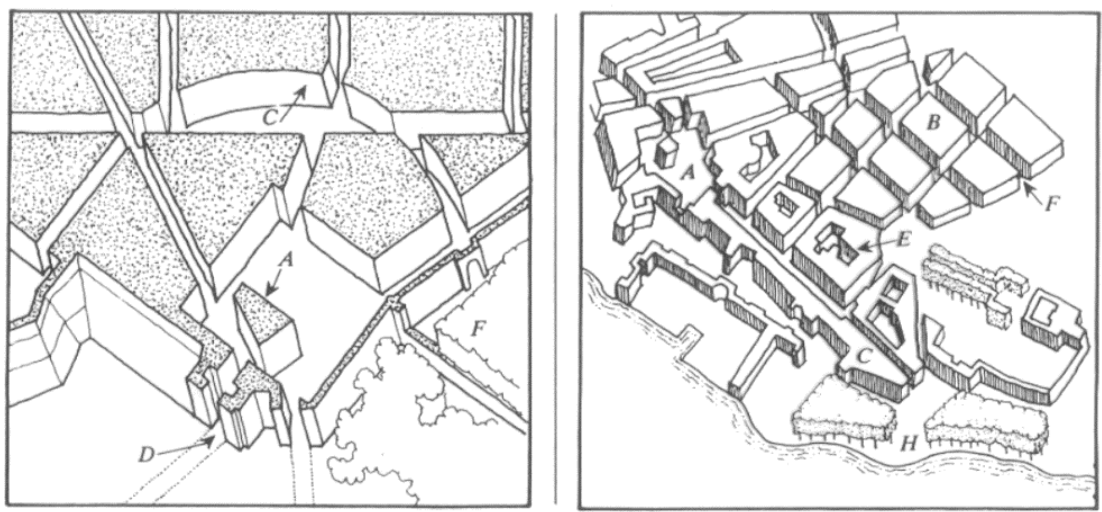

Figure 1: Type of urban solids and voids Source: Trancik (1986) 
Tan Bee Eu \& Teh Weng Jen

Figure-Ground Mapping to Identify Urban Fabric Characteristics of George Town Heritage Zone

Figure-ground maps of major cities in the world reveals fascinating relationship between solid buildings and its voids in unique identifiable patterns where no two city maps are alike (Figure 2). So, how does George Town maps out against the other major cities? The author painstakingly maps out the urban pattern of entire Heritage Zone of George Town, with its distinct pattern shown in Figure 3 below.

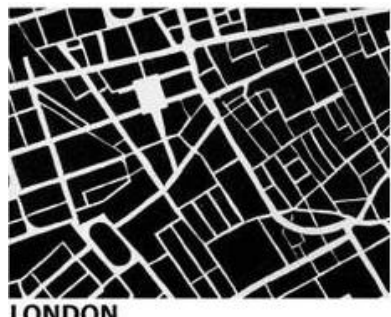

IONDON

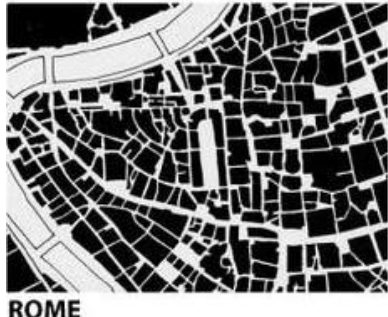

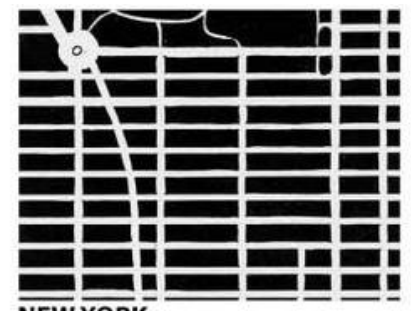

$\overline{\text { NEW }} \overline{\text { YORK }}$

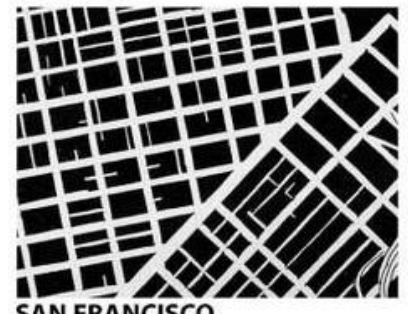

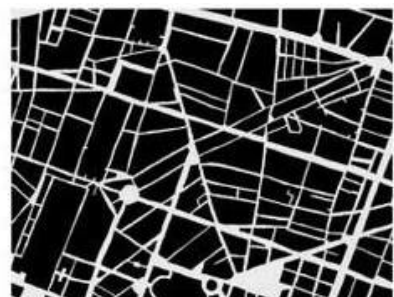
PARIS

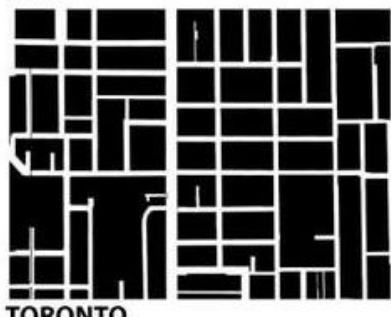

Figure 2: Figure-ground maps of major cities in the world Source: Trancik (1986)

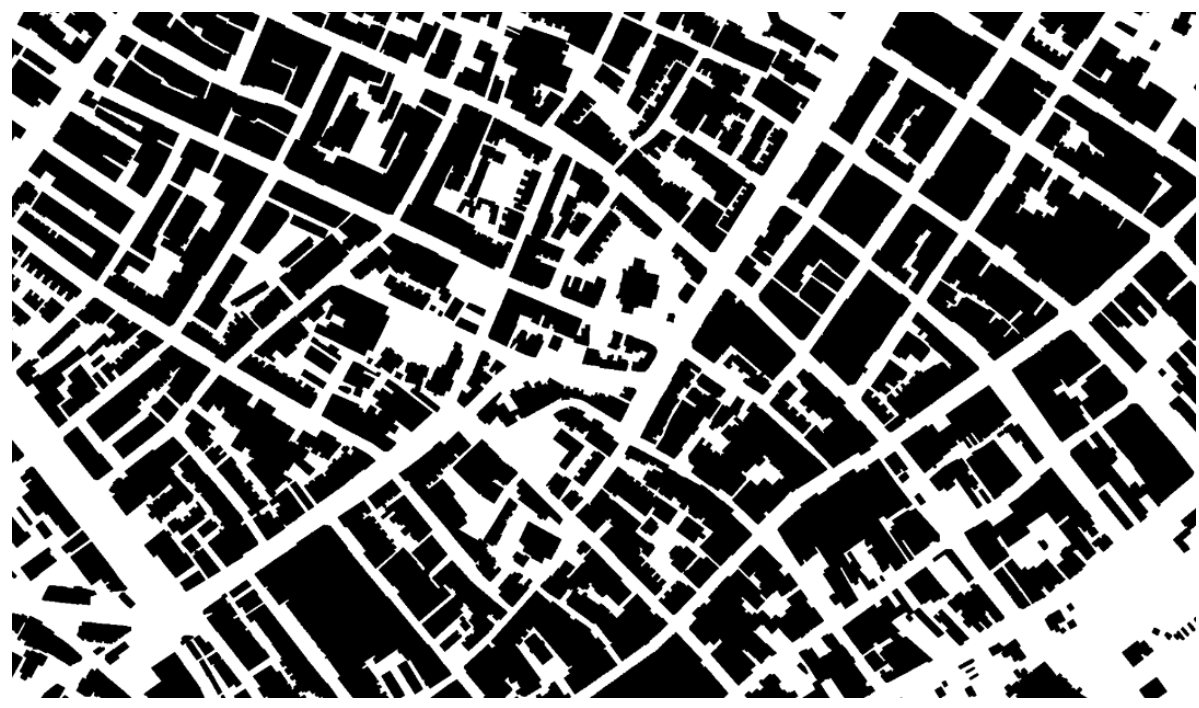

Figure 3: Figure-ground map of part of George Town Source: Author 
PLANNING MALAYSIA

Journal of the Malaysia Institute of Planners (2018)

\section{RESEARCH BACKGROUND}

\section{Understanding the Figure-ground Map of George Town}

Mapping the Figure-ground plan of George Town entails the first step in examining the urban fabric. Unlike New York's linear-grid urban pattern, George Town's figure-ground map reveals a fascinating hybrid mesh of curvilinear axis, embraced by linked-shophouse buildings on both sides, intermittently punctuated by burst of internal courtyards, open space and slim pathways of back lanes.

Broken fragments of the city fabric can be detected at weak edges of sudden open space which could be due to demolished buildings or lost spaces in between two old buildings. Its resemblance to Rome's pattern of figure-ground leaves hints for further examination comparing the two historical cities.

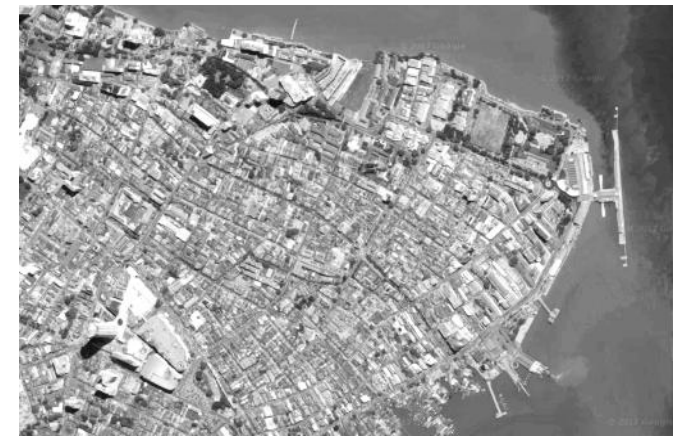

Figure 4: Satellite imaging of George Town Source: Google Maps

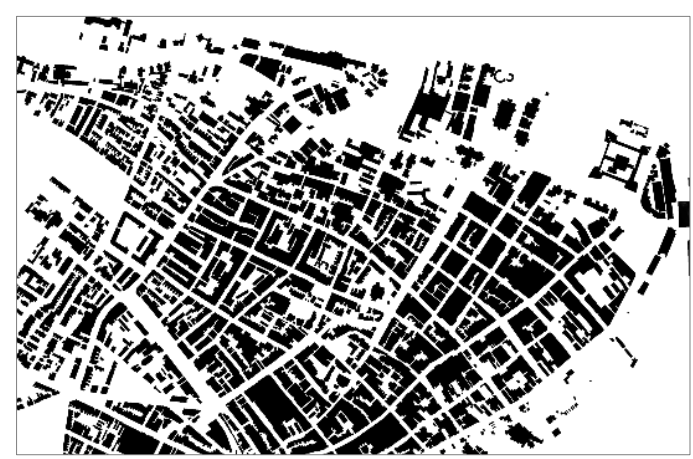

Figure 5: Figure ground mapping of George Town Heritage Zone. Source: Author

Inspired by Trancik's Integrated Approach, where figure-ground map is superimposed on the analysis of linkage studies and place theory, George Town's fabric was decrypted through an amalgamated study of two-dimensional elements, observations of links, nodes and place-making qualities. 
Tan Bee Eu \& Teh Weng Jen

Figure-Ground Mapping to Identify Urban Fabric Characteristics of George Town Heritage Zone

\section{URBAN FORM \& CHARACTERISTICS OF GEORGE TOWN}

\section{Structural Coherence}

In George Town, its fabric whole is established mainly on heavy repetition and proximity, in reference to Von Meiss's idea of structural coherence of the urban environment lists elements of repetition and similarity, proximity, enclosure and orientation. The structural form of buildings, and their relationship to the elements, of the figure-ground relationship on building frontages; and third, of the articulation of building parts. The buildings built until the Seventies have conformed to these similarities, and hence, the slight variation of their floor heights, ornamentation, materials, finishes and later the influences by Modernism have not caused severe disorder.

People recognise an identity of a place through its regularity and coherence of its parts. Our visual and mental settle on the easiness of a congruent form. What makes a congruent whole? The heritage shophouses of George Town from the Early Penang period until the Early Modern period (1790's to 1970's) share a similar building form, which had only evolved over artistic influences and the advance of building technology, however not to the extent of total chaos. Although varied by stylistic periods, the shophouses generally adapt common structural and formal characteristics: rectangular form of narrow frontage and deep length, double pitched roofs and sectional divisions of the house by courtyards and air wells. Each shophouse is linked to but articulated from its adjacent units by load bearing party walls, terraced into irregular urban blocks.

Schumacher (1996) describes it as an experience of spaces defined by continuous walls of building which are arranged in a way that emphasizes the spaces and de-emphasizes the building volumes. The experience results from a subtractive process in which spaces have been carved out of solid masses.

\section{Linkage}

The major tool that combines these shophouses into an urban fabric is largely by the imposition of covered five-foot way on the ground floor that provides physical linkages to an entire block, and visual linkages from one block to another. These linkages are further enhanced by other details, such as common roof and cornice lines. Sometimes, this continuity is disrupted by object-buildings which have functional or symbolical importance, mainly mosques or temples. Such buildings are normally built away from the proximity of the fabric, accentuated by gaps and recesses. Otherwise, in cases of limited space and capital, unique architectural solutions transpire in their relationship to the sky, the ground and the fabricbuildings in immediate contact. 
PLANNING MALAYSIA

Journal of the Malaysia Institute of Planners (2018)

\section{Facade Characters}

Rossi (1982) opines that urban artefact is the richness of the city history, its auspicious character and ominous moments of life makes it an indispensable part of the city. George Town's heritage houses is filled with micro urban artefacts on its façade. The windows, as figures, are articulated from the wall, as ground, by plaster frames or pilasters which visually extend to the ground floor, enforcing the division of the facade into three equal bays and an explicit symmetry. At the roof, the relieves were done in many interesting forms of gable ends. The roof eaves extend from the wall, suggesting its distinction from the facade. These relieves were being manipulated in different degrees - curved, pronounced, ornamented - for purposes of accentuation. The fenestrations on the facades of shophouses could be studied as series of rhythmic elements with figure-ground relationship to the solid wall. On the ground level, the central comb door with its pair of square windows and air vents are in balance to the solid wall.

\section{Articulation}

Another method of looking at the coherence of the fabric is in the articulation of the details. An articulation is a joint established between two different building components meant to define, accentuate or separate opposing elements. An explicit articulation let us recognise and trace building parts, such as to differentiate a beam from a column, wall from floor, or a tile from another. The articulation of parts in the shophouses of George Town lies muted in the transition of the plinth to the columns, columns to beams, wall to windows and to the roof. At the facade, the granite plinth of the five-foot way is articulated by the column pedestals. The bressummer beam that supports upper level to the columns is highlighted by a pair of corbel brackets. Cornices on the columns hint at the change of levels and interrupt the verticality of the facade which would otherwise become too protracted.

\section{Continuity}

However, there exists a sense of continuity created by the curves on the capital, window arches and floral plaster works on the facade. This continuity created by ornamentation was removed in shophouses built during the Art Deco and the Early Modern periods, in which the former emphasised on verticality while the latter held onto strict functionalism. Early Modern architecture had posed the most radical challenges to the fabric: disruption of figure-ground rhythms, removal of ornamental details, introduction of parapet walls, flat roof forms, simplistic edge to the elements, and opposite methods of articulation, et cetera. As such, the shophouses built under this influence had departed the most from the original form. But other factors of coherence were at hand, such as the consistency of development bay size and implied unification of the five-foot way. 
Tan Bee Eu \& Teh Weng Jen

Figure-Ground Mapping to Identify Urban Fabric Characteristics of George Town Heritage Zone

\section{IDENTIFYING UNIQUE PATTERNS AND ITS EXPERIENCE}

With an integrated approach, the figure-ground map of George Town is further analysed and key locations are identified for spatial analysis.

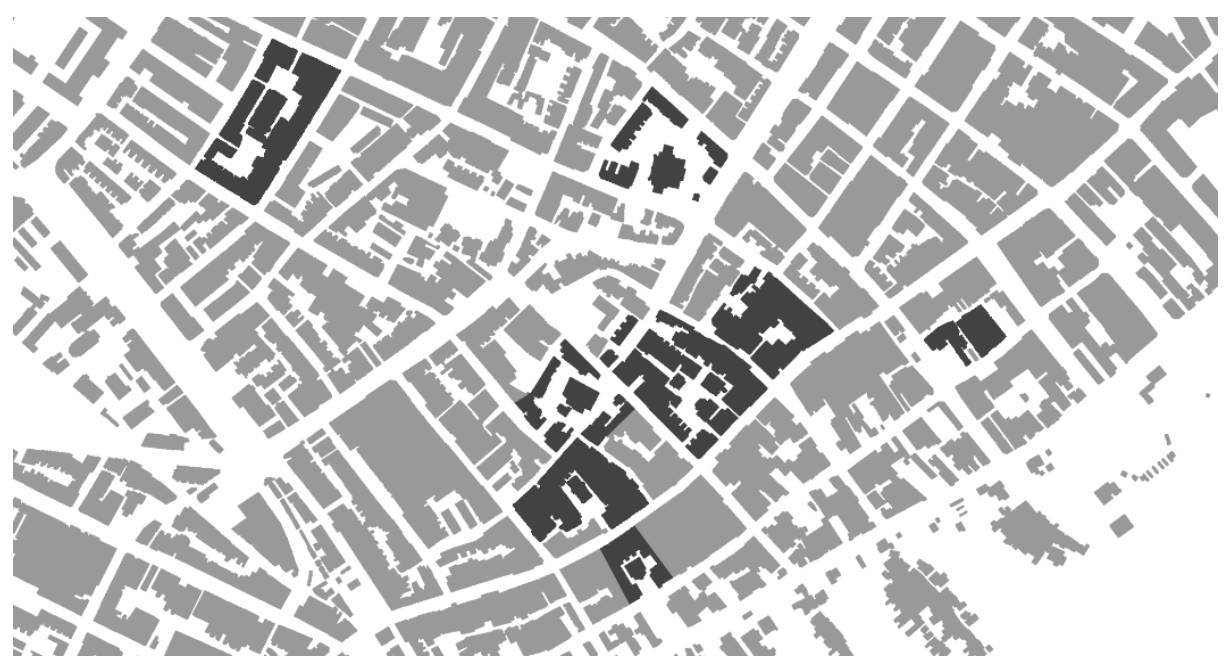

Figure 6: Selected unique patterns are identified within the entire urban fabric of figureground map of George Town Source: Author

\section{Observations of Urban Situations Archetype 01: Acheen Street Mosque}

The square at Acheen Street Mosque achieved its sense of enclosure through several qualities: restricted views and vistas, harmonious street rhythm and consistent roof lines. These are then unified not by the mosque but by its octagonal minaret facing the street opening. The tower has multiple functions as the dominating visual anchor of the square, a regional landmark and a termination of visual axis along Cannon Street all the way towards Pitt Street.

The portal from the street into the square is not any more in disguise of shophouse but instead falsely terminated by the minaret. The pedestrian travel axis seems to end abruptly, but a closer inspection reveals two separate footpaths diverged around the minaret, which one of them connects to the square. From within the square, the exact law of sight lines enforces: the view to the street is no longer offered. 
Journal of the Malaysia Institute of Planners (2018)

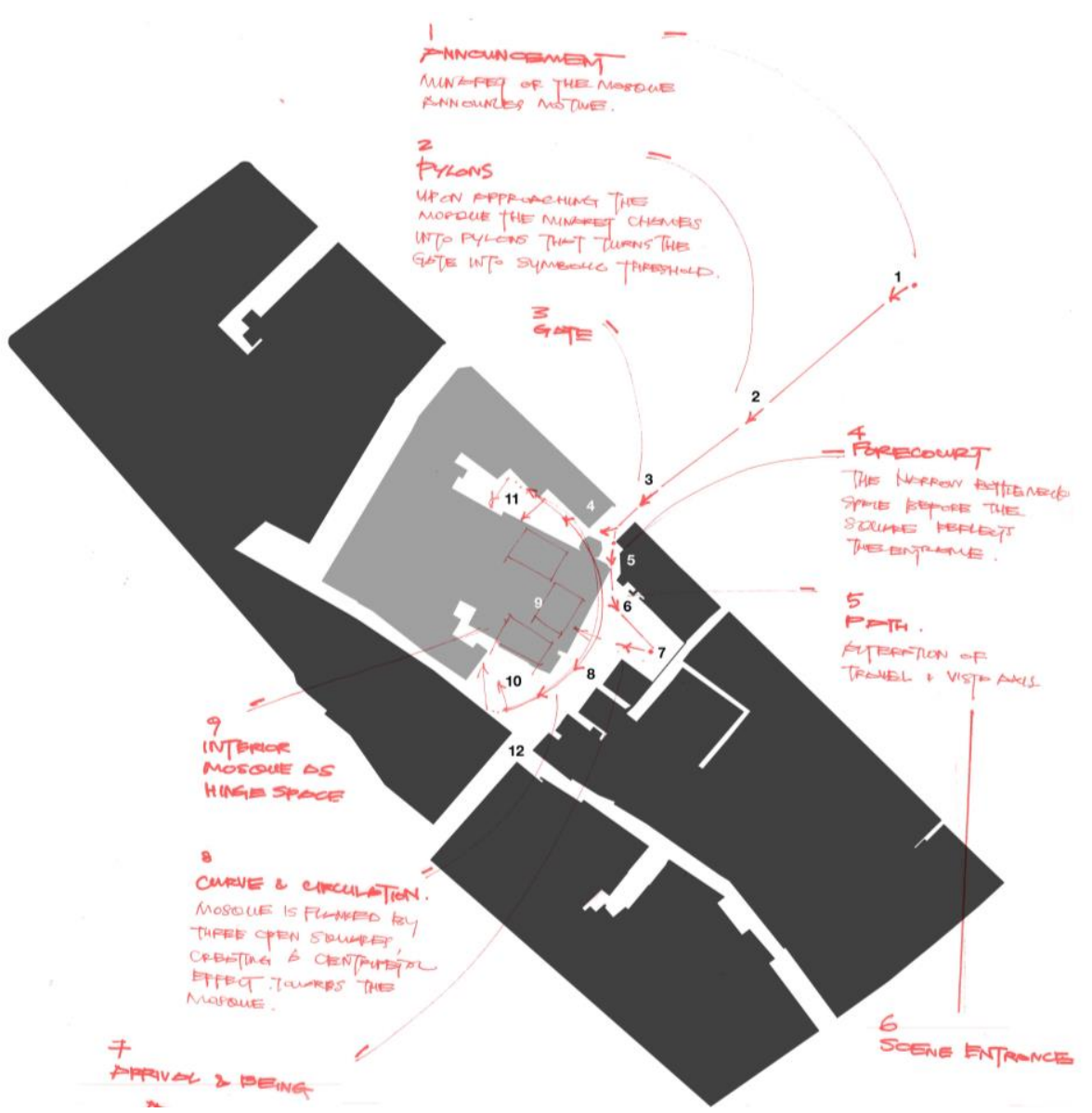

Figure 7: Analysis of figure ground of Acheen Street Mosque Source: Author

\section{Announcement}

The townscape sequence leading to the Acheen Mosque starts at the ArmenianCannon Street junction. From the road intersection one spots the minaret - a landmark that dictates the axial conclusion of the entire religious enclave that spans from Guan Yin Temple along Kapitan Keling Street. The minaret announces the destination.

\section{Pylons}

Upon approaching the mosque, one discovers the minaret stands behind a low gate. These two components form the threshold into the mosque. Here, the minaret could be referred as a pylon which turns the gate symbolic. 
Tan Bee Eu \& Teh Weng Jen

Figure-Ground Mapping to Identify Urban Fabric Characteristics of George Town Heritage Zone

\section{Gate}

A physical demarcation of entry point, the gate announces the boundary as much as a formal hint of entry.

\section{Forecourt}

The narrow space between the low gate and the minaret forms a forecourt. The function of a forecourt is to withhold visitors and provide premonition and glimpses into the spaces ahead, in this case, to the squares that flank the mosque.

\section{Path}

The unique placement of the minaret forms a deflection which hides direct vistas inward or outward the squares. The pedestrian travel axis seems to end abruptly, but a closer inspection will reveal two separate footpaths diverged around the minaret, which one of them connects to the central square.

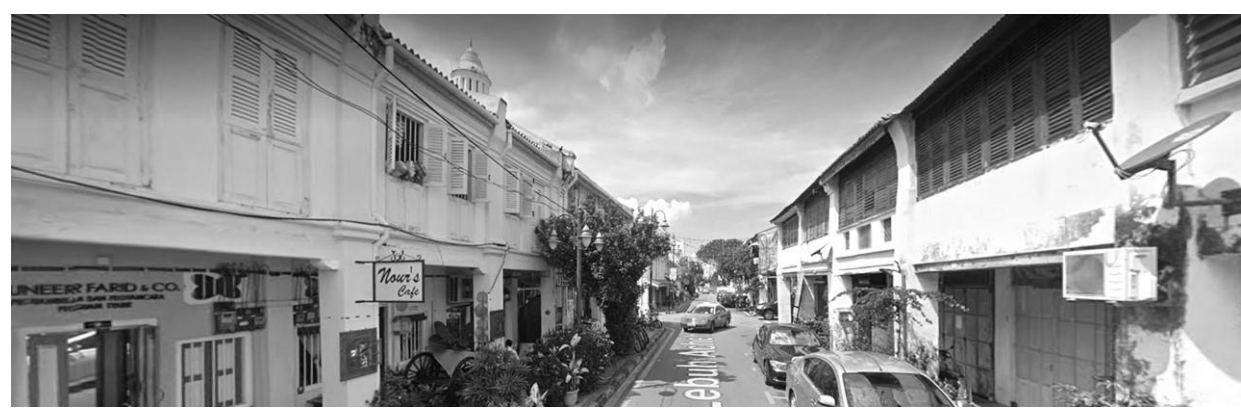

Photograph 1: Glimpse of the minaret from streetview of Acheen Street Source: Google Street Images

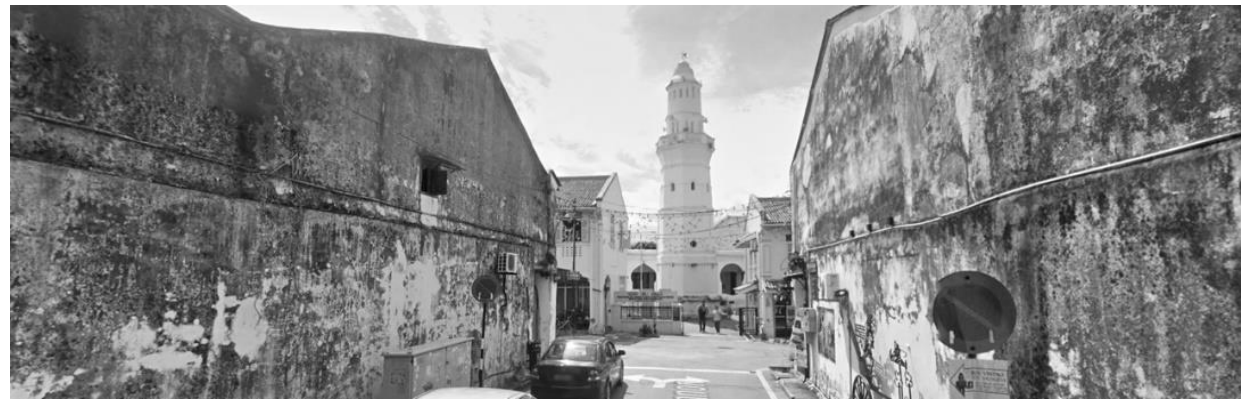

Photograph 2: Glimpse of the minaret from streetview of Cannon Street Source: Google Street Images 
PLANNING MALAYSIA

Journal of the Malaysia Institute of Planners (2018)

\section{Observations of Urban Situations Archetype 02: Khoo Kongsi, Cannon \\ Street}

Progression of experience as one enters the Khoo Kongsi can be mapped into sequential experience of 12 stages.

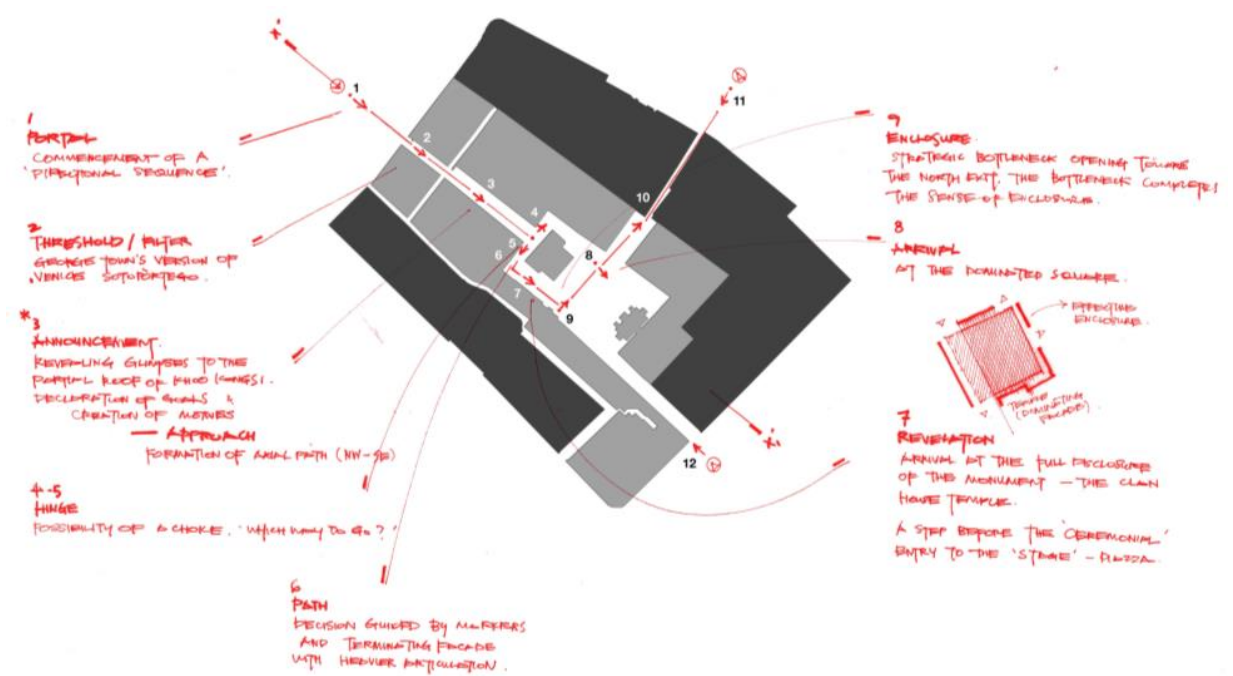

Figure 8: Figure-ground map at Leong San Tong Khoo Kongsi

Source: Author

\section{Portal}

The entrance to the clan house is disguised under identical facade with its adjoining domestic houses: a deep, dark tunnel-like space is visible from across the road, giving hints of an unknown 'otherly space' awaiting.

\section{Threshold}

Once within the tunnel, spatial qualities transforms into a threshold experience that is not merely a line or a gate. Instead, it is a transitional journey between the outside (of the portal) leading towards the inside. Similar to Venice's Sotoportego, this long threshold seem a deliberate strategy to create a filter.

\section{Announcement}

Approaching end of the dark alley, an internal street comes into view. A glimpse of a portion of a majestic roof is partially blocked by a solid wall. Sense of anticipation is evoked and a goal is now established by the roof, which now turns into a marker, or an orientation point. 
Tan Bee Eu \& Teh Weng Jen

Figure-Ground Mapping to Identify Urban Fabric Characteristics of George Town Heritage Zone

\section{Approach}

The path is indicated by the symmetrical five foot way on both sides - and thread forward. The symmetry is vital to maintain pedestrian rhythm and point a rigid direction.

\section{Hinge}

Space need for a decision arises once one arrive before the fore-mentioned wall. The small, narrow space becomes a hinge: a space that prompts one to hesitate and contemplate about the next move.

\section{Path}

The more intricate facade on the right leads the movement towards itself.

\section{Revelation}

A detour away, an oblique view of the clan house came almost abruptly. Visitors are now off the axis and standing before an open square of breadth twice the height of the clan house. From here one threads further onward and make the ceremonial entrance to the square.

\section{Arrival and Being}

Narrow space explodes into a semi-open square that is enclosed by the clan house on four-sides. The square of courtyard is large enough to soak in the architecture in totality.

\section{Enclosure}

Northward from the square, a narrow court leads further to a narrower gap. This is a 'bottleneck'. From the square, the view effectively suggests an inconspicuous exit, which remains as a strong enclosure.

\section{Tunnel}

View from the gap towards the square gives a perception of depth. Such tunneling form of a street suggests an opportunity to traverse and explore. 

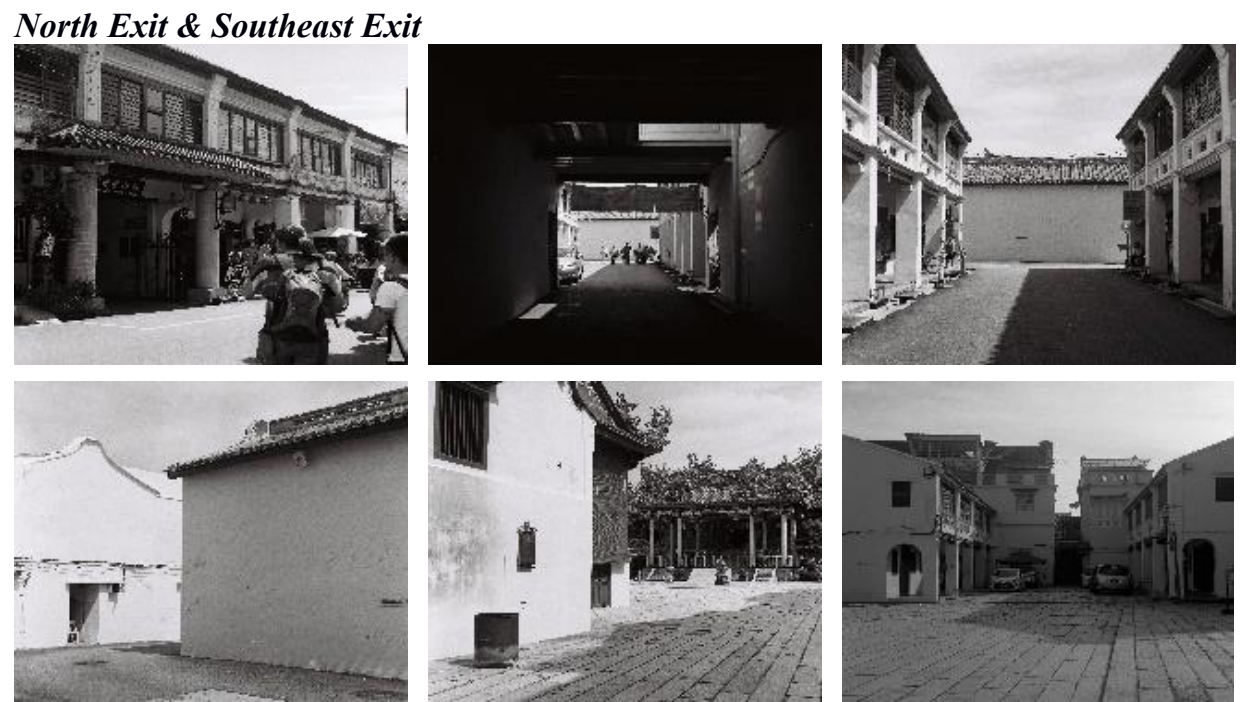

Photograph 3-8: Glimpse of the sequential experience at Khoo Kongsi Source: Author

\section{CONCLUSION}

MacEachren (1995) suggests that the human brain not only perceives but stores the essentials of a visual scene using the same geometrical, quasi-symbolic, minimalist vocabulary found in maps, such as demonstrated in the discussed Georgetown Figure-Ground Maps evoking sense of open space or narrow roads. Poulin (2011) also echoed the significance of Figure-Ground as one of the most important design principles in any visual communication.

The analysis of 2 case studies shows how figure-ground mapping could unearth fascinating spatial qualities and sequential experience. It is interesting to note that many of qualities identified from the 2 archetypes in Georgetown has been described by Alexander, Ishikawa, Silverstein and Jacobson (2013), as the positive patterns of spaces within buildings wings and between buildings. The figure-ground patterns analysed in the Khoo Kongsi displayed patterns namely Main Entrance, Half-hidden Garden, Entrance Transition, Hierarchy of Open Space, Courtyard, Cascade of Roofs.

It is hoped that urban planners and architects recognize the impact and potentials of figure-ground technique not just as a tool to analyse existing urban fabric but adapting the pattern to new adjacent township, urban infill or new buildings.

In addressing growth for a historic city, planners should begin with what Grubiak (2011) described as rethinking the historic core by strategies of infill development at the weak edges and urban voids, inward growth instead of outward, refurbishing old abandoned building and ensuring new buildings are scaled to mingle with older structures. By focusing on reconciliation and not mere 
Tan Bee Eu \& Teh Weng Jen

Figure-Ground Mapping to Identify Urban Fabric Characteristics of George Town Heritage Zone

blending, Grubiak reckons it to be the essential strategy of success to any historic city looking for equilibrium between change and continuity of relevancy.

It is by now important to appreciate that the analysis of figure-ground pattern can also contribute to ensuring the sense of place of historic city is retained and becomes an additional determining factors towards a quality neighbourhood which was categorized by Rahman (2012) as physical environment, economy and social factors.

Town Planners, architects and urban designers must have full awareness of choices to design into or out of the urban fabric. Tibbalds (2001) urged that new development should harmonize with the existing townscape, materials, historical features and local vernacular. Perhaps it shall be in such manner of abiding the subtle rules of a larger whole, that the heritage shophouses in George Town could be built, adapted and rebuilt again without jeopardising its unique urban fabric.

\section{REFERENCES}

Abdul Rahman, N. (2012). Determinant factors of neighbourhood quality. Planning Malaysia, 10, 1-16.

Alexander, C., Ishikawa, S., Silverstein, M., \& Jacobson, M. (2013). A pattern language: Towns, buildings, construction. New York, NY: Oxford Univ. Press.

Arnheim, R. (1974). Art and visual perception: A psychology of the creative eye: The revised version. Berkeley, CA: University of California Press.

Grubiak, M. (2011). Figure ground relationship. Architect, 100, 28-29.

Hebbert, M. (2016). Figure-ground: History and practice of a planning technique. Town Planning Review, 87, 705-728.

Maceachren, A. M. (1995). How maps work - Representation visualization and design. New York: The Guilford Press.

Poulin, R. (2011). The language of graphic design. Beverly, MA: Rockport Publishers.

Rossi, A. (1982). The architecture of the city. Cambridge, MA: MIT Press.

Schumacher, T. (1996). Contextualism - urban ideals and deformations. In K. Nesbitt (Ed.), Theorizing a new agenda for architecture (pp. 297-301). New York: Princeton Architectural Press.

Solomon, D. (2003). Global city blues. Washington: Island Press.

Tibbalds, F. (2001). Making people-friendly towns: Improving the public environment in towns and cities. London: E. \& F. N. Spon.

Tice, J. (2005). The Interactive Nolli Map Of Rome Website, Http://Nolli.Uoregon.Edu/Default.Asp (Accessed 12 January 2016).

Trancik, R. (1986). Finding lost space. New York: Van Nostrand Reinhold.

Wagemans, J. Elder, J. H.,Kubovy, M., Palmer, S. E., Peterson, M. A., Singh, M., \& von der Heydt, R. (2012). A century of gestalt psychology in visual perception: I. perceptual grouping and figure-ground organization. Psychological Bulletin, $138(6), 1172-1217$ 